\title{
PENGGUNAAN ALAT PELINDUNG DIRI (APD) DAN LAMA KERJA PADA KEJADIAN KECELAKAAN KERJA PENGUMPUL SAMPAH
}

\author{
Marlis Silaban,Sri Mulyati,Yusmidiarti \\ Politeknik Kesehatan Kementerian Kesehatan Bengkulu, Jurusan Kesehatan Lingkungan, \\ Jalan Indragiri Nomor 03 Padang Harapan Bengkulu \\ marlispapamama@yahoo.com
}

\begin{abstract}
Based on the results of the data obtained from the Parks Department and the Health of Bengkulu in 2013 produced garbage $291 \mathrm{~m} 3 /$ day. and the number of officers in the waste collection market Bengkulu City numbered 40 officers of garbage collectors. The purpose of this research was to determine the relationship of the application of personal protective equipment and length of employment with the incidence of occupational accidents in the garbage collector. This research used an analytical survey research methods, with a cross-sectional design. The sample was a total sampling of 40 people. Analysis used chi square with $\alpha=0.05$. The results showed no significant relationship between the application of personal protective equipment in work accident at a garbage collector $(\mathrm{p}=0.034$ and $\mathrm{OR}=7.46)$ and there were a significant relationship between length of employment with the incidence of occupational accidents at waste collection $(\mathrm{p}=0.001$ and $\mathrm{OR}=37.50)$.
\end{abstract}

Keywords : personal protective equipment, length of employment, the incidence of occupational accidents

\begin{abstract}
Abstrak : Berdasarkan hasil data dari Dinas Pertamanan dan Kebersihan Kota Bengkulu Tahun 2013 menghasilkan sampah sebanyak $291 \mathrm{~m}^{3}$ /hari dan jumlah petugas pengumpul sampah di pasar Kota Bengkulu berjumlah 40 orang petugas pengumpul sampah. Tujuan penelitian ini adalah untuk mengetahui hubungan APD dan lama kerja dengan kejadian kecelakaan kerja pada pengumpul sampah. Penelitian ini menggunakan metode penelitian survey analitik, dengan rancangan penelitian cross sectional. Sampel adalah total sampling berjumlah 40 orang. Analisis menggunakan chi Square dengan $\alpha=0,05$. Hasil penelitian menunjukkan ada hubungan yang signifikan antara pemakaian APD dengan kejadian kecelakaan kerja pada pengumpul sampah $(\mathrm{p}=0,034$ dan $\mathrm{OR}=7,46)$ serta ada hubungan yang signifikan antara lama kerja dengan kejadian kecelakaan kerja pada pengumpul sampah $(\mathrm{p}=0,001$ dan $\mathrm{OR}=37,50)$.
\end{abstract}

Kata Kunci : APD, Lama Kerja, Kejadian Kecelakaan Kerja

Berbagai aktivitas dilakukan manusia untuk memenuhi kesejahteraan hidupnya dengan memproduksi barang dan sumber daya alam selain menghasilkan barang yang akan dikonsumsi manusia dihasilkan pula bahan buangan, sehingga timbul berbagai masalah khususnya masalah kesehatan yang disebabkan semakin bertambahnya bahan buangan setiap harinya. Bahan buangan tersebut dikenal dengan istilah sampah.

Berdasarkan data dari Dinas Pertamanan dan Kebersihan Kota Bengkulu Tahun 2013 menghasilkan sampah sebanyak 291 $\mathrm{m}^{3} /$ hari. Sampah yang dihasilkan dari pasar Kota Bengkulu yaitu Pasar Barukoto, Pasar Minggu, Pasar Pagar Dewa, dan Pasar Pano- rama setiap harinya diangkut sebanyak 90 $\mathrm{m}^{3} /$ hari dan jumlah petugas pengumpul sampah di pasar Kota Bengkulu berjumlah 40 orang petugas pengumpul sampah. Sampah tersebut dikumpulkan di Tempat Penampungan Sementara (TPS) lalu diangkut dan dibuang ke Tempat Pembuangan Akhir (TPA) tanpa adanya pemilahan terlebih dahulu (Dinas Pertamanan dan Kebersihan Kota Bengkulu, 2013).

Survei awal yang dilakukan di Pasar Barukoto, Pasar Pagar Dewa, Pasar Minggu, dan Pasar Panorama pada tanggal 23-27 Desember 2012, pengumpul sampah pasar yang sehari-harinya menyapu dan mengumpulkan sampah, rata-rata mempunyai lama kerja ku- 
rang dari satu tahun, dengan pendidikan terbanyak adalah tamatan Sekolah Dasar (SD) dan umumnya berusia dewasa, yaitu di atas 20 tahun. Lama kerja seseorang berpengaruh terhadap hasil penguasaan terhadap suatu pekerjaan. Begitupun terhadap pemberian pelayanan kesehatan pada pekerja pengumpul sampah pasar juga dipengaruhi oleh lama kerja. Lama kerja pengumpul sampah pasar merupakan salah satu resiko yang mudah terinfeksi oleh penyakit kulit karena setiap petugas pengumpul sampah pasar setiap hari berhubungan dengan bau busuk sampah sehingga dapat menyebabkan dampak yang tidak baik bagi kesehatan tubuh petugas pengumpul sampah itu sendiri (Suma'mur 1988).

Dinas Pertamanan dan Kebersihan Kota Bengkulu sudah menyediakan APD kepada pengumpul sampah pasar Kota Bengkulu Tahun 2013. Masing-masing satu set (sepatu boot, helm/topi, sarung tangan karet/wol, masker dan pakaian kerja) dan alat pengumpul sampah seperti: sapu, sekop, garpu, kuie, keranjang, gerobak. Dalam melaksanakan pekerjaannya pengumpul sampah pasar mempunyai jam kerja pagi (jam 5.00-9.00 WIB) dan jam kerja sore (jam 17.00-21.00 WIB). Dari delapan orang yang bekerja, hanya lima orang yang mengenakan sepatu boot dan tiga orang yang mengenakan sarung tangan, padahal sampah yang dikumpulkan di gerobak yang kemudian diangkut ke TPS terdiri dari berbagai jenis sampah yang berisiko menimbulkan kecelakaan dan penyakit akibat kerja. Kecelakaan yang biasanya dialami delapan orang pengumpul sampah tersebut seperti: tergores atau tertusuk, tertimpa benda jatuh dan terjatuh. Kecelakaan adalah suatu kejadian yang tidak terduga dan tidak diharapkan. Kecelakaan kerja dapat menimpa setiap orang dalam melakukan pekerjaan karena kecelakaan kerja merupakan kejadian atau peristiwa yang tidak diinginkan yang merugikan manusia, merusak harta benda atau kerugian terhadap proses dalam pekerjaan (Sugandi, 2003).

Seperti kasus yang terjadi pada petugas penanganan sampah medis di beberapa Rumah Sakit di Sumatra Barat yang mengalami kecelakaan karena tidak menggunakan APD ketika kerja (Hatta, 2002). APD adalah seperangkat alat yang digunakan tenaga kerja untuk melindungi sebagian atau seluruh tubuhnya dari potensi bahaya atau kecelakaan kerja. Kepekaan yang diperlukan dalam melakukan suatu pekerjaan, misalnya untuk pekerjaan yang dimana pemakaian sarung tangan yang tipis akan memberikan kepekaan (sensibilitas) yang lebih besar dari sarung tangan yang berukuran tebal, sedangkan sepatu digunakan untuk melindungi kaki dari bahaya tertusuk benda-benda tajam dan pakaian pelindung atau pakaian kerja digunakan untuk melindungi pemakainya dari benda yang kotor, cuaca yang panas (Budiono, 2003).

Dari hasil penelitian Yusrizal (2005) di pasar Kota Payangkumbuh Sumatera Barat bahwa jenis kecelakaan kerja yang sering terjadi pada petugas pengumpul sampah yakni terjatuh, terjepit, tertimpa benda jatuh, tertusuk atau tergores dan terpotong, kasus yang menimpa para pekerja pengangkut sampah tersebut antara lain disebabkan tidak menggunakan APD yang semestinya. Berdasarkan uraian tersebut, maka penulis tertarik untuk mengetahui hubungan penggunaan Alat Pelindung Diri (APD) dan Lama Kerja dengan kejadian kecelakaan kerja pada pengumpul sampah pasar Kota Bengkulu Tahun 2013.

\section{BAHAN DAN CARA KERJA}

Penelitian ini menggunakan metode penelitian survei analitik, dengan rancangan penelitian cross sectional. Populasi dalam penelitian ini adalah pekerja yang bekerja sebagai pengumpul sampah pasar Kota Bengkulu Tahun 2013 berjumlah 40 orang petugas. Sampel dalam penelitian ini adalah (total sampling) semua petugas pengumpul sampah pasar Kota Bengkulu.

Data yang dikumpulkan dalam penelitian ini adalah data primer dan sekunder. Analisis data menggunakan univariat dan bivariat. Penelitian dilaksanakan pada bulan Februari - Maret 2013 di seluruh Pasar Kota Bengkulu. 
HASIL

\section{Analisis Univariat}

Tabel 1. Distribusi Frekuensi Responden Berdasarkan Centre penggunaan APD, Lama Kerja dan Kejadian Kecelakaan Kerja pada Pengumpul Sampah Pasar KotaBengkulu Tahun 2013

\begin{tabular}{lcc}
\hline \multicolumn{1}{c}{ Variable } & $\begin{array}{c}\text { Frekuensi } \\
(\mathbf{N = 4 0 )}\end{array}$ & $\begin{array}{c}\text { Persentase } \\
(\mathbf{1 0 0 \% )}\end{array}$ \\
\hline APD & 33 & \\
Tidak Lengkap & 7 & 82,5 \\
Pakai Lengkap & & 17,5 \\
Lama Kerja & 34 & \\
Baru(<1Tahun) & 6 & 85,0 \\
Lama (> 1Tahun) & 15,0 \\
Kejadian Kecelakaan Kerja & \\
Kecelakaan & 31 & 77,5 \\
Tidak & 9 & 22,5 \\
\hline
\end{tabular}

Berdasarkan tabel 1 diketahui bahwa sebagian besar $(82,5 \%)$ tidak menggunakan APD dengan lengkap saat mengumpulkan sampah, sebagian besar $(85,0 \%)$ mempunyai lama kerja yang baru ( $<1$ Tahun) dan sebagian besar $(77,5 \%)$ mengalami kecelakaan kerja dalam waktu tiga bulan terakhir.

\section{Analisis Bivariat}

Hasil analisis pada tabel 2 diketahui $\rho=$ $0,034<\alpha=0,05$ berarti ada hubungan yang signifikan antara penggunaan APD dengan kejadian kecelakaan kerja pada pengumpul sampah pasar Kota Bengkulu Tahun 2013 dengan $\mathrm{OR}=7,46$. Berarti pengumpul sampah yang tidak lengkap menggunakan APD akan berisiko 7,46 kali mengalami kecelakaan kerja dibandingkan dengan pengumpul sampah yang lengkap menggunakan APD.

Tabel 2 juga menunjukkan, Hasil penelitian ada hubungan yang signifikan antara Lama Kerja dengan Kejadian Kecelakaan Kerja pada Pengumpul Sampah Pasar Kota Bengkulu Tahun $2013(\rho=0,001<\alpha=0,05)$ dengan $\mathrm{OR}=37,50$. Berarti pengumpul sampah yang Baru akan berisiko 37,50 Kali mengalami Kecelakaan Kerja dibandingkan dengan pengumpul sampah yang masuk dalam kategori lama.
Tabel 2. Hubungan Penggunaan APD dan Lama Kerja dengan Kejadian Kecelakaan Kerja pada Pengumpul Sampah Pasar Kota Bengkulu Tahun 2013

\begin{tabular}{|c|c|c|c|c|c|c|c|c|}
\hline \multirow{3}{*}{ Variabel } & \multicolumn{4}{|c|}{$\begin{array}{c}\text { Kejadian } \\
\text { Kecelakaan Kerja } \\
\end{array}$} & & & \multirow{3}{*}{$\rho$} & \multirow{3}{*}{ OR } \\
\hline & \multicolumn{2}{|c|}{$\begin{array}{l}\text { Kecela- } \\
\text { kaan }\end{array}$} & \multicolumn{2}{|c|}{$\begin{array}{c}\text { Tidak } \\
\text { Kecela- } \\
\text { kaan }\end{array}$} & \multicolumn{2}{|c|}{ Total } & & \\
\hline & f & $\%$ & f & $\%$ & f & $\%$ & & \\
\hline \multicolumn{9}{|l|}{ APD } \\
\hline \multicolumn{9}{|l|}{ Tidak } \\
\hline Lengkap & 28 & 84,8 & 5 & 15,2 & 33 & 100 & \multirow[t]{2}{*}{0,034} & \multirow[t]{2}{*}{7,46} \\
\hline Lengkap & 3 & 42,9 & 4 & 57,1 & 7 & 100 & & \\
\hline \multicolumn{9}{|c|}{ Lama Kerja } \\
\hline Baru & 30 & 88,2 & 4 & 11,8 & 34 & 100 & \multirow{2}{*}{0,001} & \\
\hline Lama & 1 & 16,7 & 5 & 83,3 & 6 & 100 & & 37,50 \\
\hline
\end{tabular}

\section{PEMBAHASAN}

Hubungan penggunaan APD dengan Kejadian Kecelakaan Kerja pada Pengumpul Sampah

Hasil analisis univariat diketahui 33 responden tidak lengkap menggunakan APD. Hasil analisis bivariat menunjukan ada hubungan yang signifikan antara penggunaan APD dengan kejadian kecelakaan kerja pada pengumpul sampah pasar Kota Bengkulu Tahun $2013(\rho=0,034<\alpha=0,05)$. Pengumpul sampah yang tidak menggunakan APD akan berisiko 7,46 kali mengalami kecelakaan kerja dibandingkan pengumpul sampah yang lengkap menggunakan APD $(\mathrm{OR}=7,46)$.

Kecelakaan kerja pada pengumpul sampah yang lengkap menggunakan APD dapat terjadi dikarenakan adanya faktor peralatan yang kurang memadai apabila kondisi lampu mati karena pengumpul sampah pasar tersebut tidak membawa lampu senter saat mengumpulkan sampah pasar. Pengumpul sampah tersebut terjadi kecelakaan berupa kakinya terjatuh ke dalam selokan, sehingga kakinya tergores saat mengumpulkan sampah pasar.

Hasil penelitian ini sesuai dengan yang dikemukakan Yusrizal (2005) bahwa ada perbedaan yang signifikan antara pengumpul sampah pasar Kota Payakumbuh menggunakan APD lengkap dengan yang tidak lengkap terhadap terjadinya kecelakaan dan dermatitis kerja. APD adalah kelengkapan 
yang wajib digunakan saat bekerja sesuai bahaya dan resiko kerja untuk menjaga keselamatan pekerja itu sendiri.

Hasil ini juga didukung, Hatta (2002) tentang penggunaan APD dan frekuensi kecelakaan kerja pada petugas penanganan sampah medis di beberapa Rumah Sakit Sumatra Barat, dengan hasil ada perbedaan bermakna antara lain responden yang mengalami kecelakaan kerja karena tidak menggunakan APD dalam bekerja.

Sugandi (2003) menyatakan bahwa dalam mengumpulkan sampah masih ada sebagian besar pekerja yang belum menyadari betapa pentingnya keselamatan dan kesehatan dalam melaksanakan pekerjaan, yang hal ini terlihat dari masih banyak pekerja yang tidak memakai APD secara lengkap, walaupun APD bukan satu-satunya sarana untuk menghindari kecelakaan dan penyakit akibat kerja seperti penyakit kulit, namun APD merupakan alternatif terakhir untuk menghindari bahaya-bahaya tersebut. Kecelakaan kerja dapat menimpa setiap orang dalam melakukan pekerjaan, karena kecelakaan kerja merupakan suatu kejadian atau peristiwa yang tidak diinginkan yang merugikan manusia, merusak harta benda atau kerugian terhadap proses dalam suatu pekerjaan.

APD yang jarang digunakan oleh petugas pengumpul sampah pasar Kota Bengkulu Tahun 2013, yaitu: masker dan Topi/Helm, sedangkan APD yang sering digunakan pengumpul sampah pasar Kota Bengkulu Tahun 2013, yaitu: sarung tangan, seragam kerja dan sepatu boot. Menurut Siswanto (1991), alat pelindung diri pada petugas pengumpul sampah antara lain: alat pelindung kepala (topi/helm) untuk melindungi kepala dari bahaya akibat benda-benda jatuh dari atas kepala atau benda-benda tajam yang bisa melukai kepala, masker/penutup hidung dan mulut untuk mengurangi bau busuk sampah, alat pelindung tangan (sarung tangan), alat pelindung kaki atau sepatu boot dan pakaian kerja untuk melindungi pemakainya dari benda yang kotor, cuaca yang panas.

\section{Hubungan Lama Kerja dengan Kejadian Kecelakaan Kerja pada Pengumpul Sampah}

Hasil analisis univariat diketahui sebanyak 34 responden $(85,0 \%)$ mempunyai lama kerja yang baru. Dari hasil analisis bivariat diketahui bahwa ada hubungan yang signifikan antara lama kerja dengan kejadian kecelakaan kerja pada pengumpul sampah Pasar Kota Bengkulu Tahun 2013 ( $\rho=0,001$ $<\alpha=0,05$ ). Berarti ada hubungan yang signifikan antara Lama Kerja dengan Kejadian Kecelakaan Kerja pada Pengumpul Sampah Pasar Kota Bengkulu Tahun 2013. Pengumpul sampah yang Baru akan berisiko 37,50 kali mengalami Kecelakaan Kerja disbandingkan pengumpul sampah yang lama (OR $=37,50)$.

Kecelakaan kerja pada pengumpul sampah pasar dengan lama kerja yang lama dapat menurunkan produktivitas pengumpul sampah tersebut akibat dari efek langsung dengan sampah tersebut. Misalnya sampah beracun, sampah yang korosif terhadap tubuh, yang sampah yang karsinogenik, sampah teratogenik, dan lainnya. Selain itu ada pula sampah yang mengandung kuman patogen, sehingga dapat menimbulkan penyakit akibat dari mengumpulkan sampah setiap harinya. Hasil penelitian ini sejalan dengan penelitian Suma'mur (1995) bahwa pekerja yang mempunyai lama kerja yang lebih lama cenderung lebih kecil mendapatkan kecelakaan pekerja baru. Hal ini disebabkan oleh kurangnya keahlian dalam proses pengambilan sampah mulai dari penampungan sampah dari sumber timbunan sampah sampai ke TPS.

Menurut Ibrohim (2010) faktor yang mempengarui kejadian kecelakaan kerja pada pekerja yang bekerja kurang dari 1 tahun lebih rentan terhadap kecelakaan kerja, hal ini disebabkan kurangnya keahlian, keterampilan, pengendalian diri, pemahaman terhadap resiko keselamatan, aturan dan proses keselamatan dalam bekerja. 


\section{KESIMPULAN}

Berdasarkan hasil penelitian mengenai penggunaan alat pelindung diri (APD) dan lama kerja dengan kejadian kecelakaan kerja pada pengumpul sampah Pasar Kota Bengkulu Tahun 2013, maka dapat dibuat kesimpulan bahwa hampir sebagian besar dari responden mempunyai kebiasaan tidak menggunakan APD saat mengumpulkan sampah pasar Kota Bengkulu Tahun 2013 dan hampir semua responden mempunyai Lama Kerja <1 Tahun, sehingga ada hubungan yang signifikan antara penggunaan alat pelindung diri (APD) dan lama kerja dengan Kejadian Kecelakaan Kerja pada pengumpul sampah pasar Kota Bengkulu Tahun 2013.

Berdasarkan hasil penelitian dan pembahasan tersebut di atas, peneliti ingin mem-

\section{DAFTAR RUJUKAN}

Budiono, S. 2003. Kesehatan Kerja. Semarang. Universitas Dipenegoro.

Chandra, B. 2005. Pengantar Kesehatan Lingkungan, Jakarta : Buku Kedokteran EGC.

Departemen Kesehatan RI., 2003. Indikator Indonesia Sehat 2010. Terdapat di http.//www.depkes go.id/data\%20intranet/dokumen/indikator\%20IS -2010. Diakses tanggal 23 Desember 2013. Bengkulu.

_ 2007. Prinsip Dasar Kesehatan Kerja. Terdapat

http.//www.depkes.go.id/index.php?option=artic les\&task=viewarticle $\%$ art $\mathrm{i}=61 \%$ itemid $=3-33 \mathrm{k}$. Diakses tanggal 23 Desember 2013. Bengkulu.

Departemen Tenaga Kerja Republik Indonesia., 1992. Undang-undang No. 23 Tahun 1992.

Dinas Kebersihan dan Pertamanan Kota Bengkulu. 2013. "Daftar Rute Jalan Kerja Pengumpulan Sampah dari sumber", Bengkulu

Hatta, Z., 2002. Penggunaan Alat Pelindung Diri dan Frekuensi Kecelakaan Kerja Petugas Penanganan Sampah Medis di Beberapa Rumah Sakit Sumatera Barat. Tesis. Program Pasca Sarjana Universitas Gadjah Mada Yogyakarta.

Ismoyo, I. H. dan Rijaluzzaman., 1994. Kamus Istilah Lingkungan. Jakarta : Bina Rena Pariwara.

Mualim,dkk. 2013. Buku pedoman penulisan karya tulis ilmiah jurusan kesehatan lingkungan Politeknik Kesehatan Kementerian Kesehatan. Bengkulu : jurusan kesling. berikan saran kepada beberapa pihak yang terkait antara lain kepada pengumpul sampah pasar kota Bengkulu supaya berusaha meningkatkan kesehatan dan mengurangi bahaya kecelakaan di lingkungan kerja dan memakai alat pelindung diri (APD) yang lengkap, meliputi: topi/helm, masker, sarung tangan, sepatu boot, dan pakaian kerja pada saat melakukan aktivitas karena kecelakaan kerja dapat menimpa setiap orang dalam melakukan pekerjaan. Diharapkan kepada peneliti selanjutnya untuk melakukan penelitian lebih lanjut tentang penggunaan APD dan lama kerja dengan kejadian kecelakaan kerja pada pengumpul sampah dengan memperhatikan faktor lainnya.

Nizar, C. 2009. Komposisi dan Karakteristik Sampah. http://www.ilmusipil.com/ komposisi-dankarakteristik-sampah

Notoatmodjo, S., 2003. Ilmu Kesehatan Masyarakat. Jakarta: PT. Rineka Cipta.

2010. Metodologi Penelitan Kesehatan. Jakarta: Rineka Cipta

- 2012. Kesehatan Masyarakat Ilmu dan Seni, Jakarta : Rineka Cipta.

Pusat Kesehatan Kerja., 2007. Kesehatan dan Keselamatan Kerja Laboratorium Kesehatan. Terdapat di: http.//www.depkes.go.id/index.php?option $=$ articles\&task=viewarticle \&artid=127\&itemid= 3-41k. Diakses tanggal 27 Desember 2013. Bengkulu.

Silalahi, 1991. Manajemen Kesehatan dan Kesehatan Kerja. Jakarta: PT. Karya Unipress.

Slamet, J.S., 2004. Kesehatan Lingkungan. Yogyakarta: Gajah Mada University Press.

Sugandi, D., 2003. Bunga Rambai Hiperkes dan Kesehatan Kerja. Semarang: Universitas Dipenogoro.

Suma'mur, P.K., 1988. Higiene Perusahaan dan Kesehatan Kerja. Jakarta: PT Haji Masagung. , 1995. Keselamatan Kerja dan Pencegahan Kecelakaan. Jakarta: PT. Gunung Agung.

Wahana Lingkungan Hidup Indonesia., 2004. Mengelola Sampah Mengelola GayaHidup. Terdapat di : http//www.walhi.or.id/ kampanye/cemar/sampah pengsph-info/. Diakses tanggal 7 Januari 2013. Bengkulu. 
Widada, 2002. Hubungan Antara Perilaku Pemakaian Alat Pelindung Diri dan Personal Higiene Dengan intensitas Infeksi Cacing Perut dan Status Gizi pada Pekerja Pengangkut Sampah di Kota Yogyakarta. Gama Sain IV (1) Januari. Universitas Gadjah Mada Yogyakarta.
Yusrizal, 2005. Kecelakaan, Dermatitis Kerja dan Alat Pelindung Diri (APD) Pada Pengumpul Sampah Pasar Kota Payakumbuh Sumatera Barat, Tesis Program Pasca Sarjana Universitas Gadjah Mada Yogyakarta. 